\title{
STANDAR AKUNTANSI KEUANGAN DAN PRAKTIK MANAJEMEN LABA DI INDONESIA
}

\author{
Eni Indriani, SE., M.A. \\ Fakultas Ekonomi dan Bisnis Universitas Mataram \\ eni.indriani@unram.ac.id \\ Rahmi Sri Ramadhani, SE., M.Si. \\ Fakultas Ekonomi dan Bisnis Universitas Mataram \\ rahmisri.ramadhani@unram.ac.id \\ Widia Astuti, SE., M.Sc. \\ Fakultas Ekonomi dan Bisnis Universitas Mataram \\ widia7@ymail.com
}

\begin{abstract}
Financial reporting in Indonesia is based on accrual-based Financial Accounting Standards (SAK), where according to Watts and Zimmerman (1986) accounting recorded on an accrual basis is subject to managerial discretion, due to the flexibility given by the General Accepting Accounting Principle (GAAP), which gives managers encouragement to modify financial statements (earnings management). This study aims to map earnings management practices in Indonesia after convergent Financial Accounting Standards on IFRS. The data analysis technique used in this study is the two different test average with the $t$-test (independent sample $t$-test). The results of data analysis found that there were no significant differences. This is caused by the same earnings management pattern. The highest level of earnings management implementation exists in countries with weaker legal institutions and higher levels of pre-transition earnings management, which are partially and fully associated with market value and returns, which means that earnings management practices continue to be carried out because market demands for high rates of return on investment.

Keywords: Industrial revolution, convergence, managerial discretion, earnings management.
\end{abstract}




\begin{abstract}
ABSTRAK
Pelaporan keuangan di Indonesia berpedoman pada Standar Akuntansi Keuangan (SAK) yang berbasis akrual, dimana menurut Watts dan Zimmerman (1986) akuntansi yang dicatat dengan basis akrual merupakan subjek diskresi/keleluasaan manajerial (managerial discretion), akibat fleksibilitas yang diberikan oleh General Accepting Accounting Principle (GAAP), yang memberikan dorongan kepada manajer untuk memodifikasi laporan keuangan (manajemen laba). Penelitian ini bertujuan untuk memetakan praktik manajemen laba di Indonesia setelah Standar Akuntansi Keuangan konvergen terhadap IFRS. Teknik analisis data yang digunakan pada penelitian ini adalah uji beda dua rata-rata dengan uji-t (independent sample t-test). Hasil analisis data menemukan bahwa tidak terdapat perbedaan signifikan. Hal ini disebabkan oleh pola manajemen laba yang sama. Tingkat penerapan manajemen laba tertinggi ada di negara-negara dengan institusi hukum yang lebih lemah dan tingkat manajemen laba pra-transisi yang lebih tinggi, yang secara parsial dan penuh dikaitkan dengan nilai pasar dan tingkat pengembalian, yang berarti bahwa praktik manajemen laba tetap dilakukan karena adanya tuntutan pasar akan tingkat pengembalian atas investasi yang tinggi.

\section{Kata Kunci: Revolusi industri, konvergensi, diskresi manajerial, manajemen laba.}

\title{
PENDAHULUAN
}

\section{Latar Belakang}

Akuntabilitas merupakan suatu isu yang menjadi topik yang sangat krusial dalam dunia bisnis, terlebih di Indonesia yang menggunakan sistem pengelolaan usaha berbasis sistem dua lapis (two tier system). Fungsi pengelolaan yang dipegang manajemen memberikan mereka akses lebih terhadap seluruh informasi perusahaan, dan dalam kurun waktu tertentu memicu konflik kepentingan yang berpotensi mengancam kelangsungan hidup perusahaan. Mekanisme yang disebut sebagai upaya mengurangi konflik kepentingan antara pemilik modal dengan manajemen adalah melalui penyampaian pertanggungjawaban pengelolaan perusahaan yang disajikan dalam suatu pelaporan keuangan. Pelaporan keuangan di Indonesia berpedoman pada Standar Akuntansi Keuangan (SAK) yang berbasis akrual, dimana menurut Watts dan Zimmerman (1986) akuntansi yang dicatat dengan basis akrual merupakan subjek diskresi/keleluasaan manajerial (managerial discretion), akibat fleksibilitas yang diberikan oleh General Accepting Accounting Principle (GAAP), yang memberikan dorongan kepada manajer 
untuk memodifikasi laporan keuangan agar dapat menghasilkan laporan keuangan yang diinginkan, walaupun dapat menyebabkan distorsi dalam pelaporan laba yang dapat menyesatkan dan dapat menyebabkan pengguna laporan keuangan mengambil keputusan ekonomis yang keliru.

Kelemahan dari laporan keuangan berbasis akrual yang melibatkan banyak estimasi atau taksiran. Keleluasaan ini bisa menjadi celah yang dimanfaatkan oleh manajemen untuk melakukan perubahan terhadap laporan keuangan riil menjadi tidak riil dengan maksud untuk tujuan tertentu yang menguntungkan manajemen. Konsep yang dapat digunakan manajemen untuk mengelola laporan keuangan perusahaan agar laporan yang disajikan terlihat berkualitas dikenal dengan istilah pengelolaan laba (earnings managements).

Menyosong Era Revolusi Industri 4.0., standar akuntansi yang berbasis international mutlak diperlukan guna mengatasi kendala dan kesulitan dalam memahami laporan keuangan yang disajikan jika standar akuntansi yang dipakai antar negara beragam. Inilah yang mendorong terbentuknya standar akuntansi keuangan internasional (International Financial Reporting Standards) yang dirumuskan oleh IASB (International Accounting Standard Board). Indonesia menerapkan SAK konvergensi IFRS secara sukarela pada tahun 2011 dan mandatori pada tahun 2012.

Manfaat dari konvergensi IFRS ini adalah untuk meningkatkan kualitas laporan keuangan, antara lain dengan mengurangi kesempatan untuk melakukan manajemen laba (earning management), menyederhanakan berbagai alternatif kebijakan akuntansi yang diperbolehkan dan diharapkan untuk membatasi pertimbangan kebijakan manajemen terhadap manipulasi laba sehingga dapat meningkatkan kualitas laba. Oleh sebab itu, penelitian ini bermaksud untuk melihat pengaruh dari perubahan standar akuntansi keuangan yang digunakan setelah konvergensi IFRS terhadap praktik manajemen laba di Indonesia. Permasalahan yang dirumuskan dalam penelitian ini yaitu apakah perubahan Standar Akuntansi Keuangan yang digunakan berpengaruh terhadap praktik manajemen laba di Indonesia?

Penelitian ini bertujuan untuk memetakan praktik manajemen laba di Indonesia setelah Standar Akuntansi Keuangan konvergen terhadap IFRS. Penelitian ini diharapkan dapat memberi manfaat sebagai berikut : 1) menambah kajian terkait dengan bidang akuntansi keuangan, khususnya mengenai manajemen laba; 2) sebagai referensi dan bahan pertimbangan bagi manajemen perusahaan, investor, calon investor, dan kreditor; 3) sebagai masukan bagi pembuat kebijakan di Badan Pengawas Pasar Modal (Bapepam), Otoritas Jasa Keuangan (OJK), dan bagi Dewan Standar Akuntansi Keuangan (DSAK) dalam menyusun standar akuntansi keuangan. 


\section{TELAAH LITERATUR DAN PENGEMBANGAN HIPOTESIS}

\section{Tinjauan Teoritis}

Teori keagenan membahas hubungan antara prinsipal (pemilik dan pemegang saham) dan agen (manajemen). Jensen dan Meckling (1976) menyatakan bahwa hubungan keagenan muncul ketika satu atau lebih individu (principal) mempekerjakan individu lain (agent) untuk memberikan suatu jasa dan kemudian mendelegasikan kekuasaan kepada agen untuk membuat suatu keputusan atas nama principal tersebut. Hal ini menjadi dasar perlunya manajemen melakukan pelaporan dan pengungkapan mengenai perusahaan kepada pemilik sebagai wujud akuntabilitas manajemen terhadap pemilik.

Manajemen laba merupakan fenomena yang seringkali terjadi dalam dunia investasi di pasar modal. Menurut Sulistyanto (2008), secara umum manajemen laba didefinisikan sebagai upaya manajer perusahaan untuk mengintervensi atau mempengaruhi informasi-informasi dalam laporan keuangan dengan tujuan untuk mengelabui stakeholderyang ingin mengetahui kinerja perusahaan. Whelan dan McNamara (2004) menyatakan bahwa manajemen laba dapat digunakan sebagai indikator dari reliabilitas laba. Oleh karena itu, jika informasi keuangan perusahaan terindikasi mengandung manajemen laba, maka informasi tersebut tidak dapat diandalkan sebagai dasar pengambilan keputusan investasi.

Motivasi manajer dalam melakukan manajemen laba ada dua, yaitu oportunistik dan signaling. Teori keagenan menjelaskan bahwa manajer melakukan manajemen laba dengan cara menaikkan laba guna memanipulasi kinerja buruk dan melakukan manajemen laba dengan menurunkan laba untuk menunda kinerja baik. Sedangkan, Teori signaling menjelaskan bahwa manajer melakukan manajemen laba dengan melaporkan kenaikan laba adalah untuk memberikan sinyal bahwa laba pada masa yang akan datang akan lebih baik daripada kinerja yang diimplikasikan oleh laba nondiskresioner kini, dan melakukan manajemen laba dengan cara menurunkan laba untuk memberikan sinyal bahwa laba mendatang akan lebih buruk daripada kinerja yang diimplikasikan oleh laba non-diskresioner kini.

Untuk mengidentifikasi adanya aktivitas rekayasa manajerial terhadap laba, model-model empiris pun terus dikembangkan. Terdapat tiga kelompok model empiris atas manajemen laba yang dikelompokkan dengan basis pengukuran yang digunakan, yaitu model berbasis akrual agregat, akrual khusus, dan distribusi laba. Sulistyanto (2008), menyebutkan bahwa model berbasis akrual agregat merupakan model yang menggunakan discretionary accruals sebagai proksi manajemen laba. Pendekatan yang menghitung akrual dengan menggunakan item laporan keuangan tertentu dari industri tertentu 
merupakan model berbasis akrual khusus. Pengujian dengan membandingkan besarnya peningkatan laba secara berurutan ketika informasi keuangan terindikasi manajemen laba dan ketika tanpa manajemen laba merupakan pengelompokan dengan metode distribusi laba.

Model berbasis akrual agregat merupakan model yang paling lazim digunakan, karena dapat memberikan hasil yang paling kuat dalam mendeteksi adanya indikasi manajemen laba. Hal ini disebabkan oleh penggunaan dasar akrual dalam penyusunan laporan keuangan memungkinkan adanya perilaku manajer dalam melakukan rekayasa laba guna menaikkan atau menurunkan angka akrual dalam laporan laba rugi. Akuntansi yang dicatat dengan basis akrual (accrual basis) merupakan subjek managerial discretion, dimana menurut Watts dan Zimmerman (1986) fleksibilitas yang diberikan oleh GAAP memberikan dorongan kepada manajer untuk memodifikasi laporan keuangan agar dapat menghasilkan laporan laba seperti yang diinginkan, meskipun menciptakan distorsi dalam pelaporan laba.

Pola Manajemen Laba menurut Scott (2009) dapat dilakukan dengan cara:

1) Taking a Bath

Pola ini terjadi saat reorganisasi termasuk pengangkatan CEO baru dengan melaporkan kerugian dalam jumlah besar. Tindakan ini diharapkan dapat meningkatkan laba di masa datang.

2) Income Minimization

Dilakukan pada saat perusahaan mengalami tingkat laba yang tinggi sehingga jika laba pada periode mendatang diperkirakan turun drastis dapat diatasi dengan mengambil laba periode sebelumnya.

3) Income Maximization

Dilakukan pada saat laba menurun. Tindakan atas income maximization bertujuan untuk melaporkan net income yang tinggi untuk tujuan bonus yang lebih besar. Pola ini dilakukan oleh perusahaan yang melakukan pelanggaran perjanjian hutang.

4) Income Smoothing

Dilakukan perusahaan dengan cara meratakan laba yang dilaporkan sehingga dapat mengurangi fluktuasi laba yang terlalu besar karena pada umumnya investor lebih menyukai laba yang relatif stabil.

Standar Akuntansi Keuangan (SAK) adalah suatu kerangka dalam prosedur pembuatan laporan keuangan agar terjadi keseragaman dalam penyajian laporan keuangan. Standar Akuntansi Keuangan (SAK) merupakan hasil perumusan Komite Prinsipil Akuntansi Indonesia pada tahun 1994 menggantikan Prinsip Akuntansi Indonesia tahun 1984. SAK di Indonesia menrupakan terapan dari beberapa standard akuntansi yang ada seperti, IAS, IFRS, ETAP, GAAP. 
Selain untuk keseragaman laporan keuangan, Standar akuntansi juga diperlukan untuk memudahkan penyusunan laporan keuangan, memudahkan auditor serta memudahkan pembaca laporan keuangan untuk menginterpretasikan dan membandingkan laporan keuangan entitas yang berbeda. Di Indonesia SAK yang diterapkan akan berdasarkan IFRS pada tahun 2012.

IFRS (International Financial Reporting Standards) merupakan standar, interpretasi dan kerangka kerja dalam rangka penyusunan dan penyajian laporan keuangan yang diadopsi oleh IASB (International Accounting Standards Board). Sebelumnya IFRS ini lebih dikenal dengan nama International Accounting Standards (IAS). Konvergensi IFRS di Indonesia perlu didukung agar Indonesia mendapatkan pengakuan maksimal. Pengakuan maksimal ini didapat dari komunitas internasional yang sudah lama menganut standar ini. Jurang pemisah terdalam PSAK dengan IFRS telah teratasi yaitu dengan diperbolehkannya penggunaan nilai wajar (fair value) dalam PSAK.

Manfaat dari konvergensi IFRS ini adalah: 1) Memudahkan pemahaman atas laporan keuangan dengan penggunaan Stan-dar Akuntansi Keuangan yang dikenal secara internasional (enhance comparability). 2) Meningkatkan arus investasi global melalui transparansi. 3) Menurunkan biaya modal dengan membuka peluang fund raising melalui pasar modal. 4) Menciptakan efisiensi penyusunan laporan keuangan. 5) Meningkatkan kualitas laporan keuangan, antara lain dengan mengurangi kesempatan untuk melakukan earning management.

Dewan Standar Akuntansi Keuangan Ikatan Akuntan Indonesia (DSAKIAI) telah memulai proses konvergensi IFRS sejak 2009 dan diharapkan selesai sebelum awal tahun 2012. Sasaran konvergensi IFRS tahun 2012 adalah merevisi PSAK agar secara material sesuai dengan IFRS versi 1 Januari 2009 yang berlaku efektif 1 Januari 2012. Untuk memperlancar proses adopsi IFRS keberhasilan masa transisi adalah kunci utamanya. langkah efektif yang perlu dilakukan perusahaan selama masa transisi adalah membentuk tim adhoc konvergensi IFRS yang bertanggung jawab untuk melakukan persiapan awal dan mengorganisasikan sumber daya. Selain itu dibutuhkan kesiapan dari para praktisi, antara lain akuntan manajemen, akuntan publik, akuntan akademisi dan kesiapan para regulator maupun profesi pendukung lain, seperti penilai dan aktuaris. 
Eni Indriani, dkk: Standar Akuntansi Keuangan dan Praktik Manajemen Laba di Indonesia

\section{METODE PENELITIAN}

\section{Rancangan Penelitian}

Penelitian ini merupakan penelitian eksplanasi, yaitu penelitian yang dilakukan dengan maksud untuk menjelaskan kedudukan variabel-variabel yang diteliti serta hubungan antara satu variabel dengan variabel lainnya (Anshori dan Iswati, 2009:12).

Populasi adalah wilayah generalisasi yang terdiri atas subyek yang mempunyai kualitas dan karakteristik tertentu yang ditetapkan oleh peneliti untuk dipelajari dan kemudian ditarik kesimpulannya (Anshori dan Iswati, 2009:92). Populasi dalam penelitian ini adalah perusahaan manufaktur yang terdaftar di Bursa Efek Indonesia (BEI) selama kurun waktu 2012-2017.

\section{Definisi Operasional}

Manajemen Laba adalah pengungkapan manajemen sebagai alat intervensi langsung manajemen dalam proses pelaporan keuangan melalui pengolahan pendapatan atau keuntungan, dengan maksud untuk mencapai tujuan yang sudah ditetapkan manajemen. Manajemen laba (earning anagement) dapat diukur melalui discreationary acrual sebagai proksi manajemen laba yang dihitung dengan menggunakan Modified Jones Model. Model perhitungannya sebagai berikut:

\section{$\mathrm{Ta}_{\text {it }}=\mathrm{N}_{\text {it }}-\mathrm{CFO}_{\text {it }}$}

Nilai total accrual yang diestimasi dengan persamaan regresi OLS sebagai berikut:

$$
T_{i t} / A_{i t-1}=a\left(1 / A_{i t-1}\right)+a\left(\Delta R e c / A_{i t-1}\right)+a\left(P P E t / A_{i t-1}\right)+e
$$

Dari persamaan regresi diatas, NDA dapat dihitung dengan rumus:

$N D A_{i t}=a\left(1 / A_{i t-1}\right)+a\left(\Delta S_{1}\right.$ lesit $\left./ A_{i t-1}-\Delta R e c_{i t} / A_{i t-1}\right)+\left(P P E t / A_{i t-1}\right)$

Selanjutnya DA dapat dihitung sebagai berikut:

$$
D A_{i t}=\left(T_{i t} / A_{i t-1}\right)-N D A_{i t}
$$

Keterangan:

$\mathrm{DA}_{\text {it }}=$ Discreationary Accruals perusahaan i pada periode $\mathrm{t}$

$\mathrm{NDA}_{\text {it }}=$ Non Discreationary Accruals perusahaan i pada periode $\mathrm{t}$

$\mathrm{TA}_{\mathrm{it}} \quad=$ Total Accruals perusahaan i pada periode $\mathrm{t}$

Nit $\quad=$ Laba bersih perusahaan $\mathrm{i}$ pada periode $\mathrm{t}$

$\mathrm{CFO}_{\text {it }} \quad=$ Aliran kas dari aktivitas perusahaan pada periode $\mathrm{t}$

Ait-1 = Total aktiva perusahaan $\mathrm{i}$ pada periode $\mathrm{t}$

$\triangle$ SALES $_{\text {it }} \quad=$ Selisih sales perusahaan i pada periode $\mathrm{t}$ 
$\Delta$ Recit $_{\text {it }} \quad=$ Perubahan piutang perusahaan i pada periode $\mathrm{t}$

PPEt $\quad=$ Nilai aktiva tetap (gross) perusahaan $\mathrm{i}$ pada periode $\mathrm{t}$

e

= error

International Financial Report Standard (IFRS) adalah standar pelaporan keuangan berbasis global yang merupakan kerangka kerja dalam rangka penyusunan dan penyajian laporan keuangan yang diadopsi oleh IASB (International Accounting Standards Board). IFRS diterbitkan sebagai upaya untuk memperkuat arsitektur keuangan global dan mencari solusi jangka panjang terhadap kurangnya transparansi informasi keuangan.

\section{Prosedur Analisis Data}

Penelitian ini terdiri dari serangkaian kegiatan sistematis yang dilakukan untuk menjawab rumusan masalah yang diajukan. Langkah pertama yang dilakukan adalah menghitung nilai discretionary accrual (DACC), setelah itu menganalisis apakah terdapat praktik manajemen laba atau tidak untuk kemudian memetakan pola manajemen laba yang digunakan dengan melihat jenis industri, dan tingkat risiko industri. Terkait dengan periode penerapan Standar Akuntansi Keuangan yang berterima umum yang diterapkan pada periode pengamatan, digunakan teknik analisis data uji beda dua rata-rata dengan uji-t (paired sample t-test) untuk membandingkan rata-rata dari dua sampel yang berpasangan yaitu untuk melihat apakah berbeda atau sama pada tingkat signifikansi $\propto=0,05$. Adapun data yang menjadi kriteria dalam menentukan apakah terdapat tidaknya perbedaan manajemen laba sebelum dan sesudah Penerapan Standar Akuntansi Keuangan (Konvergensi IFRS) adalah sebagai berikut :

a. Jika nilai Sig. (2-tailed) $<0,05$, maka terdapat perbedaan yang signifikan antara praktik manajemen laba sebelum dan sesudah penerapan SAK Konvergensi IFRS.

b. Jika nilai Sig. (2-tailed) $>0,05$, maka tidak terdapat perbedaan yang signifikan antara praktik manajemen laba sebelum dan sesudah penerapan SAK Konvergensi IFRS.

Setelah hasil uji beda diperoleh, selanjutnya peneliti memetakan praktik manajemen di Indonesia pasca Standar Akuntansi Keuangan konvergen terhadap IFRS berdasarkan, teknik pengelolaan laba, pola manajemen laba, dan jenis industri. 


\section{HASIL PENELITIAN DAN PEMBAHASAN}

\section{Gambaran Umum Objek Penelitian}

Penelitian ini bertujuan untuk mengetahui praktik manajemen laba di Indonesia setelah penerapan Standar Akuntansi Keuangan yang konvergen terhadap International Financial Reporting Standards (IFRS). Penelitian dilakukan dengan mengambil sampel pada perusahaan manufaktur yang terpilih berdasarkan metode purposive sampling dengan beberapa kriteria yang telah ditetapkan pada bab sebelumnya. Terdapat 70 perusahaan manufaktur yang terpilih menjadi sampel dengan periode pengamatan dari tahun 2011 sampai dengan 2017. Uji beda independent sample t-test dilakukan pada tahun terdekat dengan penerapan IFRS secara mandatory di Indonesia, yaitu tahun 2012. Periode sebelum penerapan IFRS adalah tahun 2011 dan sesudahnya adalah tahun 2013. Selanjutnya, untuk periode pengamatan dari tahun 2014 hingga tahun 2017, peneliti akan melakukan uji tambahan jika terdapat indikasi signifikan akan perbedaan pola manajemen laba dengan 3 (tiga) periode pengamatan utama $(2011,2012$, dan 2013). Selain uji beda, penelitian ini juga dimaksudkan untuk memetakan pola dan teknik manajemen laba yang dipraktikkan pada perusahaan manufaktur sepanjang periode pengamatan.

\section{Analisis Data}

\section{Statistik Deskriptif}

Olah data dilakukan dengan bantuan SPSS 19, hasil olah data untuk statistik deskriptif dapat dijabarkan sebagai berikut: pada tahun 2011, ratarata nilai Discretionary Accrual (manajemen laba) adalah sebesar -0,1808, yang berarti bahwa terdapat praktik manajemen laba pada perusahaan manufaktur dengan pola income decreasing (penurunan laba). Rata-rata nilai Discretionary Accrual (manajemen laba) pada tahun 2012 adalah sebesar 0,1502 , yang berarti bahwa terdapat praktik manajemen laba pada perusahaan manufaktur dengan pola income decreasing (penurunan laba). Setelah penerapan IFRS tahun 2013, rata-rata nilai Discretionary Accrual (manajemen laba) adalah sebesar $-0,1740$, yang berarti bahwa terdapat praktik manajemen laba pada perusahaan manufaktur dengan pola income decreasing (penurunan laba).

\section{Analisis Uji Beda}

Hasil uji beda independent sample t-test yang telah dilakukan dengan bantuan SPSS 19 untuk periode pengamatan tahun 2011 dan 2012 menemukan bahwa angka Sig (2-tailed) sebesar 0,178. Oleh karena nilai Sig. (2-tailed) $>0,05$, maka tidak terdapat perbedaan yang signifikan antara praktik 
manajemen laba sebelum dan sesudah penerapan SAK Konvergensi IFRS. Uji beda independent sample t-test untuk periode pengamatan tahun 2012 dan 2013 menemukan bahwa angka Sig (2-tailed) sebesar 0,352, dimana diketahui nilai Sig. (2-tailed) > 0,05, yang bermakna tidak terdapat perbedaan yang signifikan antara praktik manajemen laba sebelum dan sesudah penerapan SAK Konvergensi IFRS.

Tidak terdapatnya beda signifikan antara praktik manajemen laba sebelum (tahun 2011) dan sesudah (tahun 2013) penerapan SAK Konvergensi IFRS, ditindaklanjuti dengan melakukan uji beda tambahan atas tahun penelitian dengan indikasi rata-rata nilai Discretionary Accrual (DA) yang berbeda. Pada tahun 2014 rata-rata nila DA perusahaan manufaktur adalah sebesar 0,00846, yang berarti bahwa yang berarti bahwa terdapat praktik manajemen laba pada perusahaan manufaktur dengan pola income increasing (peningkatan laba). Hasil olah data menunjukkan bahwa angka Sig (2-tailed) sebesar 0,000. Oleh karena nilai Sig. (2-tailed) < 0,05, maka terdapat perbedaan yang signifikan antara praktik manajemen laba sebelum dan sesudah penerapan SAK Konvergensi IFRS.

\section{Interpretasi Hasil Analisis Uji Beda}

Manajemen laba merupakan suatu upaya pengelolaan laba yang dilakukan oleh manajemen perusahaan dalam rangka memenuhi tujuan yang ingin dicapai. Cara-cara yang dipraktikkan dalam pengelolaan laba ini masih menjadi perdebatan hingga kini, namun apabila pengelolaan laba dilakukan dengan memanfaatkan metode akuntansi yang diperkenankan oleh Standar Akuntansi Keuangan yang berterima umum, maka praktik ini tidak memiliki kecenderungan negatif. Hasil uji beda yang telah dilakukan menunjukkan bahwa tidak terdapat praktik manajemen laba yang signifikan sebelum dan setelah penerapan SAK yang konvergen dengan IFRS, hal ini disebabkan karena pola manajemen yang diterapkan sama, namun ketika pola manajemen laba yang diterapkan berbeda, maka hasil uji beda menunjukkan terdapat perbedaan signifikan sebelum dan setelah penerapan SAK yang konvergen dengan IFRS. Walaupun demikian, yang perlu diperhatikan adalah bahwa baik sebelum maupun setelah penerapan SAK IFRS ini, manajemen perusahaan tetap melakukan manajemen laba, meskipun dengan pola, teknik dan level manajemen laba yang berbeda.

Kesimpulannya adalah bahwa praktik manajemen laba pada perusahaan manufaktur di Indonesia pada transisi ke penerapan SAK yang konvergen dengan IFRS, tetap dilakukan walaupun dengan penerapan SAK yang berbeda. Menurut Capkun et.al (2008) manajemen laba transisi ini hadir di semua negara, tetapi levelnya tertinggi di negara-negara dengan institusi hukum yang 
lebih lemah dan tingkat manajemen laba pra-transisi yang lebih tinggi. Hasil ini konsisten dengan manajer yang menggunakan transisi untuk meningkatkan laba dan ROA yang dilaporkan. Rekonsiliasi pendapatan dalam IFRS baik secara parsial maupun penuh dikaitkan dengan nilai pasar dan tingkat pengembalian, yang berarti bahwa praktik manajemen laba tetap dilakukan karena adanya tuntutan pasar akan tingkat pengembalian atas investasi yang tinggi.

\section{PENUTUP}

Rangkaian prosedur analisis data yang telah dilakukan guna mengetahui pengaruh perubahan Standar Akuntansi Keuangan terhadap praktik manajemen laba sebelum (tahun 2011) dan sesudah (tahun 2013) International Financial Reporting Standard (IFRS), menemukan bahwa tidak terdapat perbedaan signifikan. Hal ini disebabkan oleh pola manajemen laba yang sama. Tingkat penerapan manajemen laba tertinggi ada di negara-negara dengan institusi hukum yang lebih lemah dan tingkat manajemen laba pratransisi yang lebih tinggi, yang secara parsial dan penuh dikaitkan dengan nilai pasar dan tingkat pengembalian, yang berarti bahwa praktik manajemen laba tetap dilakukan karena adanya tuntutan pasar akan tingkat pengembalian atas investasi yang tinggi.

Bidang industri yang berbeda menyebabkan perbedaan terkait dengan komponen pembentuk laba. Sehingga penting untuk dilakukan penilaian manajemen laba pada industri-industri yang berbeda, guna mengetahui sebaran praktik manajemen laba diseluruh bidang industri yang ada di Indonesia. Oleh karena dalam penelitian ini terdapat batasan fokus pada industri manufaktur, maka disarankan kepada peneliti selanjutnya untuk menilai sebaran pada industri lain, sehingga dampak perubahan standar terhadap praktik manajemen laba dapat memberikan kajian yang lebih komprehensif, guna pengambilan keputusan ekonomi yang lebih baik bagi semua stake holder yang membutuhkan informasi terkait.

\section{DAFTAR PUSTAKA}

Anshori, Muslich dan Sri Iswati. 2009. Buku Ajar Metodologi Penelitian Kuantitatif. Surabaya: Pusat Penerbitan dan Percetakan UNAIR (AUP).

Capkun, Vedran, Anne Cazavan_Jeny, Thomas Jeanjean, dan Lawrence A. Weiss. 2008. Earnings Management and Value Relevamce during the Mandatory Transition from Local GAAPs to IFRS in Europe. SSRN. 2011.

Ikatan Akuntan Indonesia. 2007. Standar Akuntansi Keuangan. Jakarta: Salemba Empat. 
Jensen, M.C., and W. H. Meckling. 1976. Theory of The Firm: Manajerial Behaviour, Agency Cost, and Ownership Structure. Journal of Financial and Economics, 3, 305-360.

Scott, William R. 2009. Financial Accounting Theory (5th Edition). Pearson Education. Toronto, Canada. 2009.

Shleifer, A. and R.W. Vishny. 1997. A Survey of Corporate Governance. Journal of Finance, Vol.52. No.2. June, p.737-783.

Sugiyono. 2013. Metode Penelitian Kombinasi. Bandung: Penerbit Alfabeta.

Sulistyanto, Sri. 2008. Manajemen Laba: Teori dan Model Empiris. Jakarta: PT. Gramedia Widiasarana Indonesia.

Watts, R., and J.L. Zimmerman. 1990. Positive Accounting Theory. The Accounting Review. Vol 65, No. 1.

Whelan, Catherine J., dan Raymond P. McNamara. 2004. The Impact of Earnings Management on the Value-Relevance of Earnings and Book Value: A Comparison of Short-term and Long-term Discretionary Accruals. JEL Classifications: G12, G14, and M41. 